\title{
PEMODELAN PERUBAHAN TATAGUNA LAHAN TERHADAP DEBIT BANJIR DAS TANGGUL, JEMBER MENGGUNAKAN MODEL SWAT (SOIL AND WATER ASSESSMENT TOOL)
}

\author{
Diah Ainunisa $^{* 1}$, Gusfan Halik ${ }^{2}$ dan Wiwik Yunarni Widiarti ${ }^{2}$ \\ ${ }_{1}$ Mahasiswa, S1 Teknik Sipil, Fakultas Teknik, Universitas Jember \\ 2 Dosen, Teknik Sipil, Fakultas Teknik, Universitas Jember \\ *Korespondensi: dainunisa22@gmail.com
}

\begin{abstract}
Population growth is one of the causes of land-use change that can increase runoff. Tanggul watershed is one of the watersheds which often overflows during the rainy season. This study purpose to analyze the effect of land-use changes on runoff in Tanggul watershed using SWAT (Soil and Water Assessment Tool) model. To make sure the performance of SWAT model calibration and classified by the value of NSE and $R^{2}$. The result of calibration included in a good category and validation included in a very good category. This study was modeling forest land-use change in 2004-2017 to determine the effect of land-use change on runoff. The result in this model of forest land-use change can increase runoff.
\end{abstract}

Keywords : flood modeling, land-use change, Tanggul watershed, SWAT

\section{PENDAHULUAN}

Semakin banyak penduduk suatu daerah maka semakin banyak juga lahan yang dibutuhkan untuk dijadikan sebagai tempat tinggal maupun penunjang. Jember merupakan salah satu Kabupaten di Indonesia yang memiliki jumlah penduduk yang banyak. Hingga 12 Maret 2015 berdasarkan data BPS Kabupaten Jember dengan luas lahan 3,292 km², Jember memiliki penduduk sebanyak 2,333 juta jiwa dan belum ditambah dengan penduduk rantau yang menetap di Jember untuk keperluan pendidikan, pekerjaan, maupun urusan lainnya.

Pengolahan lahan yang baik akan memberikan dampak yang baik bagi penduduk sekitar, begitu juga sebaliknya. Banjir merupakan salah satu bencana alam yang terjadi jika pengolahan lahan tidak diatur dengan baik. Banjir dapat terjadi akibat beberapa faktor seperti perubahan fisiologis lahan, letak anakanak sungai disekitar DAS, bentuk DAS dan sedimen[1]. DAS Tanggul merupakan salah satu DAS yang berada di Kabupaten Jember dan termasuk salah satu DAS yang sering meluap pada saat musim hujan. Pendekatan pemodelan merupakan salah satu cara yang mudah dilakukan untuk memprediksi sebab terjadinya banjir pada suatu DAS. Pemodelan DAS sering digunakan untuk menilai respon hidrologi DAS terhadap perubahan penggunaan lahan, perubahan iklim dan perubahan karakteristik lainnya [2]. Pada umumnya pemodelan banyak menggunakan perangkat lunak yang dapat memudahkan analisis terjadinya banjir.

SWAT (Soil and Water Assessment Tool) merupakan salah satu perangkat lunak extention Arc-GIS yang dapat mengidentifikasi permasalahan DAS. Adapun beberapa DAS yang telah berhasil dimodelkan menggunakan SWAT dalam mengidentifikasi banjir akibat pengaruh tataguna lahan adalah sebagai berikut: Zanjanrood, Barat Daya Iran[3]; Sungai Nzoia, Kenya[4]; Sungai Njoro, Afrika Utara[5]; Sungai Godavari, India[6] ; DAS Cisadane, Indonesia[7] dan Sungai Sub-DAS Metro, Indonesia[8]. Oleh karena itu, untuk mengetahui besarnya pengaruh perubahan tataguna lahan terhadap pengaruh debit banjir yang terjadi di DAS Tanggul penelitian ini akan menganalisis pengaruh perubahan tataguna lahan terhadap debit banjir pada DAS Tanggul dengan menggunakan model SWAT (Soil and Water Assessment Tool). 


\section{TINJAUAN PUSTAKA}

\subsection{Siklus Hidrologi}

Siklus hidrologi merupakan proses sirkulasi air dari atmosfer ke bumi dan kembali lagi ke atmosfer melalui proses kondensasi, presipitasi, evaporasi dan transpirasi [9]. Siklus hidrologi memiliki peranan penting bagi keberlangsungan hidup organisme bumi. Melalui siklus ini, ketersediaan air dapat tetap terjaga karena proses siklus hidrologi mempengaruhi suhu lingkungan, cuaca, hujan hingga keseimbangan ekosistem [9].

\subsection{DAS (Daerah Aliran Sungai)}

DAS (Daerah ALiran Sungai) merupakan suatu wilayah kesatuan ekosistem yang dibatasi oleh pemisah topografi dan berfungsi sebagai pengumpul, penyimpan dan penyalur air, sedimen, unsur hara melalui system sungai serta mengeluarkannya melalui outlet tunggal (danau/laut)[9].

Menurut Suripin, 2004 terdapat beberapa faktor karakteristik DAS yang dapat mempengaruhi besarnya limpasan total, antara lain: luas dan bentuk DAS, topografi dan tataguna lahan.

\subsection{Analisis Hidrologi}

\subsubsection{Curah Hujan Hilang}

Data curah hujan dapat disebabkan oleh beberapa hal, seperti kerusakan alat ukur, tidak ada pengamatan atau data pengamatan hilang. Menurut Soemarto, 1987 pengisian data curah hujan hilang dapat dilakukan dengan menggunakan model rasio normal yang dapat dilihat pada persamaan 1 .

$$
D x=\frac{1}{n} \sum_{i=1}^{n} d_{i} \frac{A n_{x}}{A n_{i}}
$$

$\mathrm{D}_{\mathrm{x}} \quad=$ Data hujan hilang $(\mathrm{mm})$

$\mathrm{An}_{\mathrm{x}} \quad=$ Tinggi hujan rata-rata pada stasiun $\mathrm{x}$ (mm)

$\mathrm{An}_{\mathrm{i}} \quad=$ Tinggi hujan rata-rata pada stasiun hujan disekitar stasiun $\mathrm{x}(\mathrm{mm})$

$\mathrm{d}_{\mathrm{i}} \quad$ = Hujan yang sama dengan hujan yang akan dicari dari stasiun lain (mm)

$\mathrm{n}=$ jumlah stasiun hujan sekitar stasiun $\mathrm{x}$

\subsubsection{Uji Konsistensi Data Curah Hujan}

Uji konsistensi data dilakukan untuk menguji apakah data yang didapat terdapat kesalah atau mengandung data kosong. Uji ini dapat dilakukan dengan metode analisis kurva massa ganda yang dapat menunjukkan konsistensi data.

\subsubsection{Debit Aliran}

Debit aliran merupakan komponen yang penting dalam pengelolaan suatu DAS. Debit aliran atau aliran sungai adalah laju aliran (volume air) yang melewati penampang melintang persatuan waktu yang dinyatakan dalam satuan SI $\left(\mathrm{m}^{3} / \mathrm{dt}\right)$ [8]. Salah satu analisis debit aliran mengenai pengaruh perubahan tataguna lahan dapat dilakukan dengan perhitungan terhadap bilangan kurva aliran $\mathrm{CN}$ (Curve Number) sebagai salah satu variabel penentu perubahan DAS. Metode yang telah dikembangkan oleh SCS (Soil Conservation Service) dengan memperhatikan CN merupakan fungsi dari karakteristik DAS seperti tipe tanah, tanaman penutup, tataguna lahan, kelembaban hingga cara pengerjaan tanah. Adapun nilai-nilai $\mathrm{CN}$ yang akan menjadi parameter pada pemodelan SWAT dapat dilihat pada Tabel 1.

Tabel 1. Nilai CN untuk Penggunaan Kelompok Tutupan Lahan

\begin{tabular}{lccccc}
\hline \multirow{2}{*}{ Tutupan Lahan } & Kode & \multicolumn{3}{c}{ Kel. Jenis Tanah } \\
\cline { 3 - 6 } & SWAT & A & B & C & D \\
\hline Tegalan & RNGB & 67 & 78 & 85 & 89 \\
Hutan & FRST/FRSE & 36 & 60 & 73 & 79 \\
Tanah Kosong & OAK & 39 & 61 & 74 & 80 \\
Kebun Campur & ORCD & 32 & 58 & 72 & 79 \\
Sawah & RICE & 61 & 73 & 81 & 84 \\
Pemukiman & URBN & 31 & 59 & 72 & 79 \\
\hline
\end{tabular}

Sumber: Theoretical Documentation ArcSWAT, 2012

\subsection{Arc-SWAT (Soil and Water Assessment Tool)}

Soil and Water Assessment Tools yang disingkat SWAT adalah model prediksi untuk skala daerah aliran sungai (DAS). Model SWAT dapat memprediksi dampak perubahan lahan terhadap air, sedimen dan bahan kimia pertanian yang masuk ke sungai atau badan air lainnya pada suatu DAS. Proses simulasi hidrologi untuk mendapatkan debit pada model SWAT terdiri dari deliniasi areal penelitian, pembentukan HRU (Hydrology Response Unit) dan running SWAT. Proses pemodelan pada SWAT yang terjadi di dalam DAS didasarkan pada neraca air yang ditunjukkan pada persamaan 2 . 
$S W_{t}=S W_{0}+\sum_{i=1}^{t}\left(R_{\text {day }}-Q_{\text {surf }}-E_{a}-w_{\text {seep }}-Q_{g w}\right)$

Dengan:

SWt = kandungan air tanah akhir (mm)

Swo = kandungan air tanah permulaan hari 1 $(\mathrm{mm})$

$\mathrm{t} \quad=$ waktu (hari)

Rday = jumlah curah hujan pada hari i (mm)

Qsurf = jumlah aliran permukaan pada hari $\mathrm{i}$ (mm)

$\mathrm{Ea} \quad=$ jumlah evapotranspirasi pada hari $\mathrm{i}$ (mm)

Wseep = jumlah air yang masuk ke dalam zone vadose pada profil tanah pada hari i (mm)

Pengujian model SWAT dapat dilakukan dengan kalibrasi dan validasi model. Kalibrasi dan validasi model dapat dilakukan dengan pendekatan nilai NSE (Nash-Sutfcliffe Model Efficiency) dan $\mathrm{R}^{2}[10]$. Adapun kriteria nilai NSE dan R2 dapat dilihat pada Tabel 2.

Tabel 2. Nilai CN untuk Penggunaan Kelompok Tutupan Lahan.

\begin{tabular}{ccl}
\hline NSE & \multicolumn{1}{c}{$\mathrm{R}^{2}$} & \multicolumn{1}{c}{ Klasifikasi } \\
\hline $0.75<\mathrm{NSE} \leq 1.00$ & $0.75<\mathrm{R}^{2} \leq 1.00$ & Sangat Baik \\
\hline $0.60<\mathrm{NSE} \leq$ & $0.60<\mathrm{R}^{2} \leq 0.75$ & Baik \\
0.75 & & \\
\hline $0.36<\mathrm{NSE} \leq$ & $0.50<\mathrm{R}^{2} \leq 0.60$ & Memuaskan \\
0.60 & & \\
\hline $0.00<\mathrm{NSE} \leq$ & $0.25<\mathrm{R}^{2} \leq 0.50$ & Buruk \\
0.36 & & \\
\hline $\mathrm{NSE} \leq 0.00$ & $\mathrm{R}^{2} \leq 0.25$ & Tidak Memenuhi \\
\hline
\end{tabular}

Sumber: R.A. Amleida dkk, 2018

\section{METODOLOGI}

\subsection{Lokasi Penelitian}

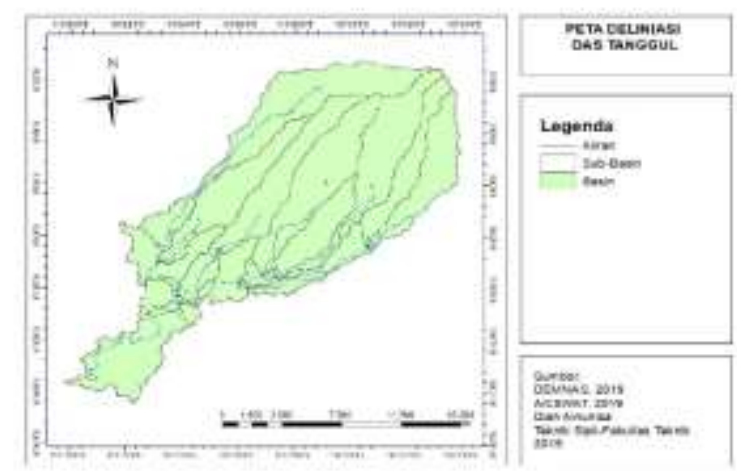

Gambar 1. Peta DAS Tanggul
Penelitian ini dilakukan di DAS Tanggul yang secara geografis terletak pada $8^{\circ} 05^{\prime} 55^{\prime}$ " LS - $113^{\circ} 30^{\prime} 00^{\prime \prime}$ BT. Pemodelan pada SWAT menggunakan batas DAS Tanggul hingga DAM Pondok Waluh (Gambar 1).

\subsection{Pengumpulan Data}

Penelitian ini membutuhkan dua macam data yaitu data spasial dan non-spasial. Data spasial terdiri dari peta DEM yang didapatkan di http://tides.big.go.id/DEMNAS/DEMNAS.php, peta tataguna lahan, peta jenis tanah dan peta kemiringan lereng dari BPDAS HL Brantas Sidoarjo. Data non-spasial terdiri dari data curah hujan, debit dan klimatologi yang diperoleh dari Dinas PSDA Lumajang.

\subsection{Tahapan Penelitian}

\subsubsection{Analisis Hidrologi}

Analisis hidrologi pada penelitian ini dimulai dengan analisis data curah hujan hilang pada seluruh data curah hujan stasiun hujan yang digunakan pada DAS Tanggul dengan menggunakan model rasio normal seperti pada persamaan 1. Jika tidak ditemukan data hilang maka atau telah mengisi data curah hujan yang hilang, analisis dilanjutkan dengan menguji konsistensi data curah hujan dengan penilaian $\mathrm{R}^{2}$. Kualifikasi data dikatakan konsisten jika nilai $\mathrm{R}^{2}$ mendekati 1 .

\subsubsection{Pemodelan Arc-SWAT}

Pada tahap pemodelan ini terdapat tiga langkah utama untuk mendapatkan nilai debit model. Langkah pertama yaitu pembentukan deliniasi areal penelitian menggunakan peta DEM (Digital Elevation Model). Langkah kedua yaitu pembentukan HRU (Hydrology Response Unit) menggunakan data-data peta tataguna lahan, jenis tanah dan kemiringan lereng. Langkah ketiga yaitu SWAT Run and Setup yang merupakan tahap pengaturan waktu simulasi dan keluaran model yang disesuaikan dengan data curah hujan dan klimatologi.

\subsubsection{Kalibrasi dan Validasi Model}

Kalibrasi dan validasi pada pemodelan ini dilakukan terhadap dua macam tataguna lahan yang diukur dengan mengklasifikasikan nilai NSE dan $\mathrm{R}^{2}$ seperti pada Tabel 2. Perbedaan kalibrasi dan validasi terhadap tataguna lahan yang digunakan yaitu untuk tataguna lahan 2009 menggunakan data curah hujan tahun 20072010 untuk kalibrasi dan data curah hujan tahun 2011-2012 untuk validasi sedangkan untuk tataguna lahan 2017 menggunakan data curah 
hujan tahun 2013-2016 untuk kalibrasi dan data curah hujan 2017-2018 untuk validasi. Hal ini dilakukan untuk mendapatkan hasil keandalan yang maksimal.

\section{PEMBAHASAN}

\subsection{Analisis Hidrologi}

Pemodelan pada penelitian ini menggunakan 16 stasiun hujan yang tersebar di DAS Tanggul sebagai sumber data curah hujan tahun 2007-2018. Data stasiun hujan dan data curah hujan pada penelitian ini diperoleh dari Dinas PSDA Lumajang. Adapun 16 stasiun hujan yang digunakan pada penelitian ini dapat dilihat pada Tabel 3. Analisis yang pertama dilakukan yaitu mengecek kelengkapan data curah hujan. Pengecekan data curah hujan pada setiap stasiun tidak ditemukan adanya data hilang maupun kosong. Oleh karena itu analisis dilanjutkan dengan melakukan uji konsistensi data curah hujan dengan kurva massa ganda yang memperhatikan nilai $\mathrm{R}^{2}$. Kualifikasi data dikatakan konsisten apabila $\mathrm{R}^{2}$ mendekati nilai 1. Berdasarkan hasil perhitungan dan analisis pada data setiap stasiun hujan menghasilkan kualifikasi konsisten seluruhnya. Adapun contoh hasil perhitungan uji konsistensi pada stasiun hujan DAS Tanggul dapat dilihat pada Tabel 3.

Tabel 3. Hasil Uji Konsistensi Stasiun Hujan DAS Tanggul

\begin{tabular}{ccc}
\hline Stasiun Hujan & $\mathrm{R}^{2}$ & Keterangan \\
\hline Bedodo & 0.9949 & Konsisten \\
Darungan & 0.9925 & Konsisten \\
GumukmasKT & 0.9938 & Konsisten \\
Gumukmas BT & 0.9949 & Konsisten \\
Kencong 1 & 0.9949 & Konsisten \\
Kencong 2 & 0.997 & Konsisten \\
Pladingan & 0.9965 & Konsisten \\
Pondok Joyo 1 & 0.9881 & Konsisten \\
Pondok Joyo 2 & 0.9808 & Konsisten \\
Pondok Waluh & 0.9953 & Konsisten \\
Semboro & 0.9964 & Konsisten \\
Tanggul & 0.9949 & Konsisten \\
Tanjung Rejo & 0.9981 & Konsisten \\
Watu Urip & 0.9958 & Konsisten \\
Wonorejo & 0.9945 & Konsisten \\
Wringin Agung & 0.9809 & Konsisten \\
\hline
\end{tabular}

Setelah uji konsistensi data pada data curah hujan, langkah selanjutnya yaitu memindahkan nilai-nilai curah hujan dan data klimatologi dalam bentuk. *txt untuk dijadikan bahan input SWAT.

\subsection{Pengolahan Data Input ArcSWAT}

Pengolahan peta DEM merupakah hal pertama yang harus dilakukan untuk melakukan pemodelan suatu DAS pada SWAT. Pengolahan peta DEM harus diproyeksikan terlebih dahulu pada koordinat UTM Indonesia Zona 49S dengan datum WGS 1985 dengan program ArcGIS 10.4 (Gambar 2).

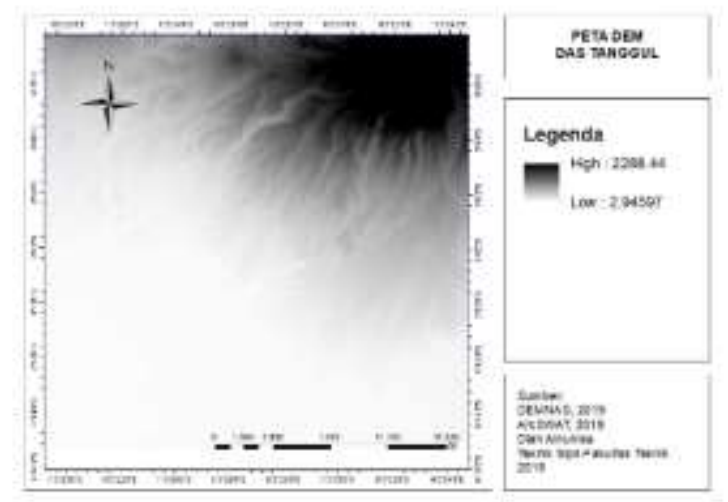

Gambar 2.Peta DEM (Digital Elevation Model)

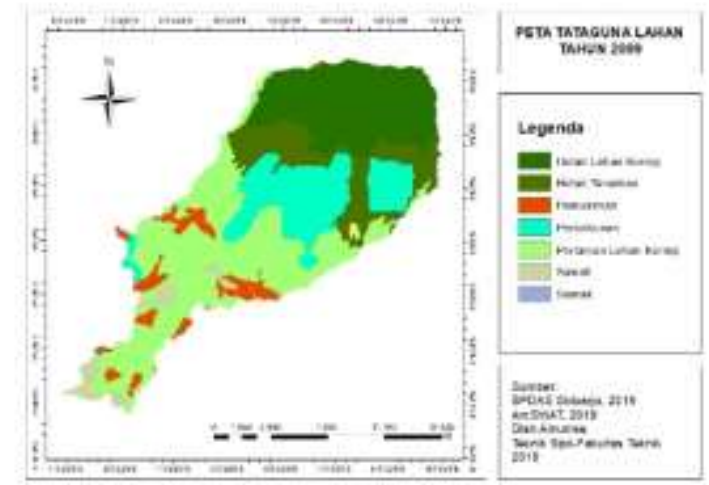

Gambar 3. Peta Tataguna Lahan Tahun 2009

Langkah selanjutnya yaitu analisis data peta tataguna lahan, peta jenis tanah dan peta kemiringan lereng dengan program ArcGIS 10.4. Analisis ini digunakan untuk kalibrasi dan validasi model SWAT yang menggunakan dua jenis peta tataguna lahan yaitu peta tataguna lahan tahun 2009 dan 2017 untuk peta jenis tanah maupun kemiringan lereng digunakan satu jenis data yang sama. Data peta-peta yang digunakan diperoleh dari BPDAS HL Brantas 
Sidoarjo. Hasil analisis ArcGIS 10.4 untuk peta tataguna lahan dapat dilihat pada Gambar 3 untuk tahun 2009 dan Gambar 4 untuk tahun 2017.

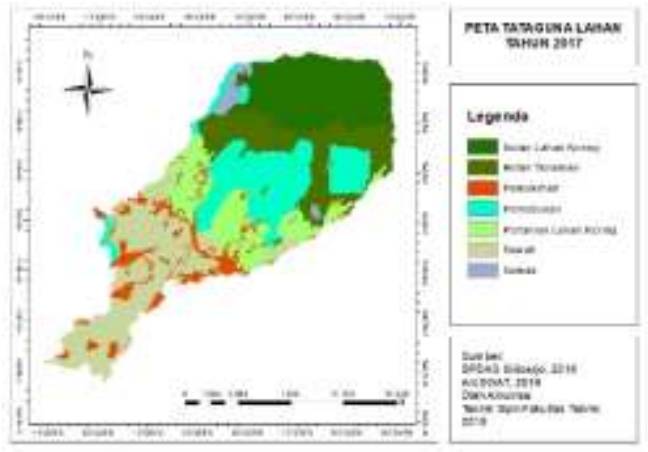

Gambar 4. Peta Tataguna Lahan Tahun 2017

Analisis selanjutnya dilakukan pada peta jenis tanah yang menghasilkan 3 jenis tanah yaitu Latosol, Aluvial dan Andosol yang dapat (Gambar 5). Sedangkan untuk hasil analisis pada peta kemiringan lereng terdapat 5 klasifikasi kelerengan (Gambar 6).

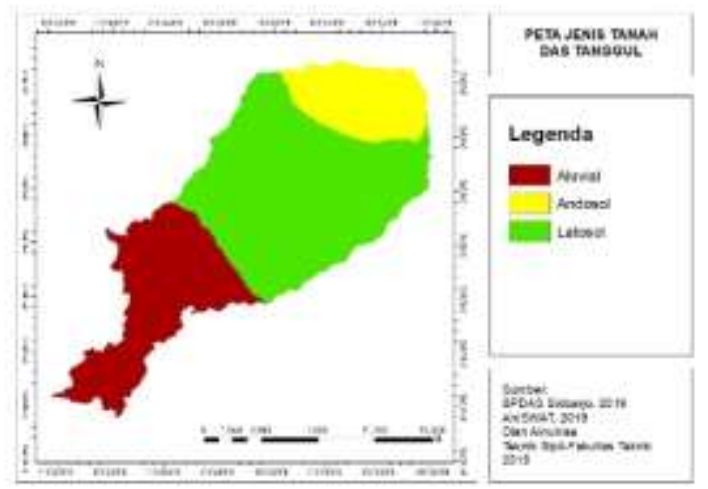

Gambar 5. Peta Jenis Tanah

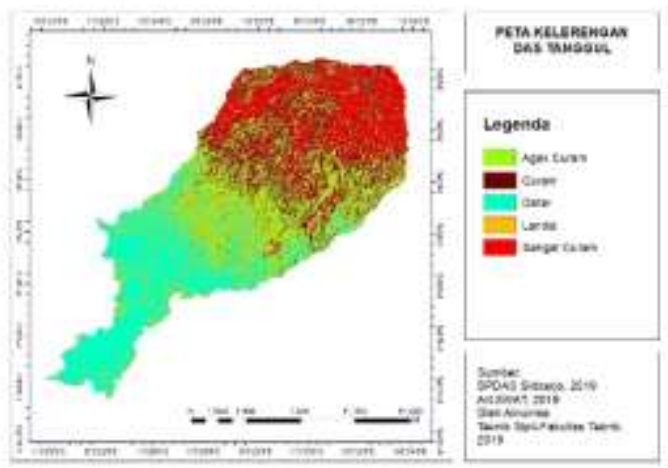

Gambar 6. Peta Kemiringan Lereng

\subsection{Pemodelan ArcSWAT}

Pemodelan ArcSWAT dimulai dengan input peta DEM (Gambar 2) yang akan dijadikan sebagai bahan deliniasi DAS. Deliniasi DAS dilakukan secara otomatis dengan cara menentukan titik outlet pada pe DEM. Titik outlet yang dipilih pada pemodelan ini adalah DAM Pondok Waluh sehingga membentuk ba-tas DAS dengan luas 264.39 $\mathrm{Km}^{2}$ (Gambar 7).

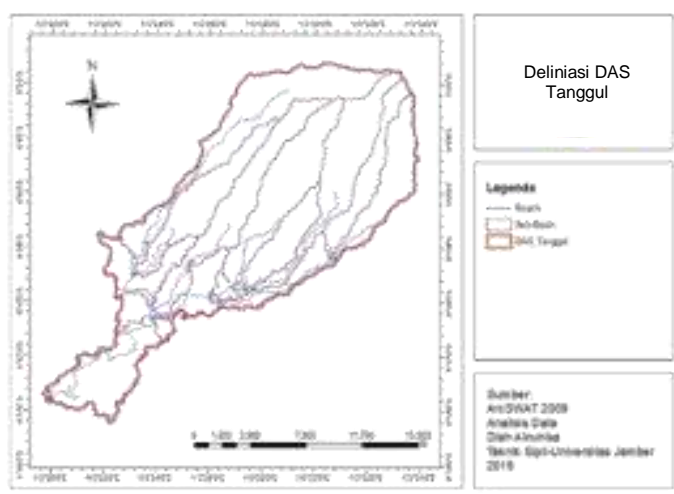

Gambar 7. Deliniasi DAS Tanggul

Proses selanjutnya yaitu pembentukan HRU (Hydrology Response Unit) yang merupakan proses overlay dari peta-peta tataguna lahan, jenis tanah dan kemiringan lereng. Pada penelitian ini terdapat dua macam pembentukan HRU dikarenakan melakukan analisis data pada dua tataguna lahan berbeda. Pembentukan HRU pada kedua tataguna lahan menghasilkan 15 subbasin dengan masingmasing 342 HRUs untuk tataguna lahan 2009 dan 425 HRUs untuk tataguna lahan 2017.

Setelah pembentukan HRU berhasil, langkah selanjutnya yaitu melakukan running model dengan masing-masing simulasi pada kedua model tataguna lahan berbeda. Pada tataguna lahan 2009 untuk tahap kalibrasi running dilakukan pada tahun 2007-2010 dan untuk tahap validasi running dilakukan pada tahun 2011-2012. Pada tataguna lahan 2017 untuk tahap kalibrasi running dilakukan pada tahun 2013-2016 dan untuk tahap validasi running dilakukan pada tahun 2017-2018.

\subsection{Kalibrasi dan Validasi Model} 4.4.1. Kalibrasi Model

Kalibrasi model dilakukan terhadap dua model tataguna lahan berbeda yaitu model tataguna lahan 2009 dan 2017. Hal ini dilakukan karena selama tahun data yang dipakai dalam 
penelitian ini telah terjadi perubahan klim maupun tataguna lahan yang mempengaruhi keandalan model. Kalibrasi dilakukan evaluasi berdasarkan nilai NSE dan $\mathrm{R}^{2}$ yang dinyatakan dalam grafik dan scatter plot pada penelitian ini. Kalibrasi dilakukan dengan mengubah parameter model untuk mendapatkan nilai keandalan maksimal dengan metode trial and error secara manual. Adapun hasil kalibrasi parameter pada masing-masing model tataguna lahan dapat dilihat pada Tabel 4. Setelah dilakuakan kalibrasi pada kedua model, didapatkan nilai debit model yang selanjutnya kembali dibandingkan dengan debit observasi.

Pada model tataguna lahan 2009 dilakukan kalibrasi debit tahun 2007-2010 menghasilkan $\mathrm{NSE}=0.78$ dan $\mathrm{R}^{2}=0.86$ (Gambar 8 dan 9) kategori sangat baik. Kalibrasi pada model tataguna lahan 2017 dilakukan terhadap debit tahun 2013-2016 menghasilkan NSE=0.74 dan $\mathrm{R}^{2}=0.94$ (Gambar 10 dan 11).

Tabel 4. Parameter Kalibrasi ArcSWAT

\begin{tabular}{ccccc}
\hline \multirow{2}{*}{ Parameter } & \multicolumn{2}{c}{ TGL 2009 } & \multicolumn{2}{c}{ TGL 2007 } \\
\cline { 2 - 5 } & Nilai & Nilai & Nilai & Nilai \\
& Awal & Akhir & Awal & Akhir \\
\hline CN2 & 77 & 89 & 77 & 89 \\
ESCO & 0.95 & 1 & 0.95 & 1 \\
GWQMN & 1000 & 50 & 1000 & 300 \\
ALPHA_BF & 0.048 & 1 & 0.048 & 0.95 \\
GW_DELA & 31 & 21 & 31 & 16 \\
Y & 0 & 120 & 0 & 150 \\
CH_K2 & 0.21 & 0.01 & 0.21 & 0.01 \\
SOL_AWC & 0.21 &
\end{tabular}

Sumber: Hasil Analisis ArcGIS, 2019

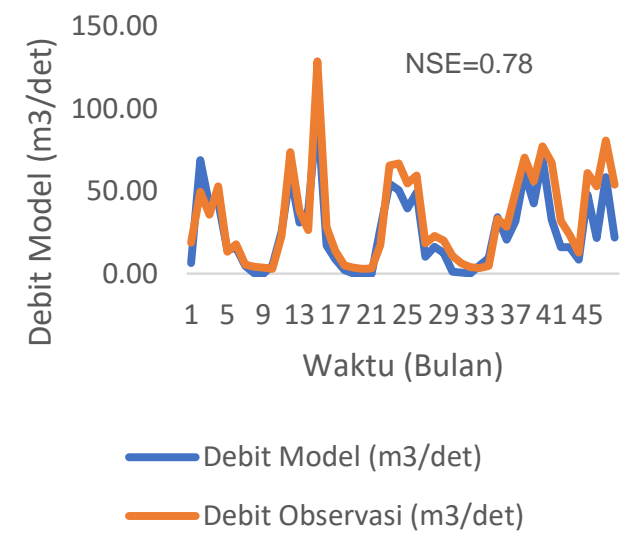

Gambar 8. Grafik Kalibrasi Tataguna Lahan 2009

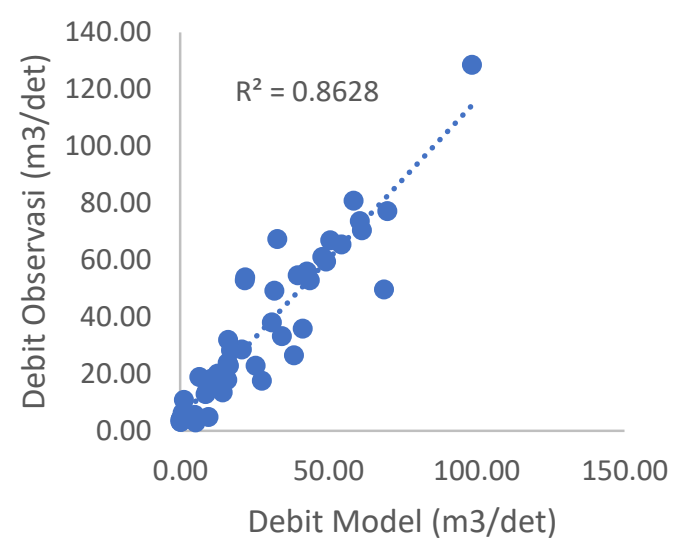

Gambar 9. Scatter Plot Kalibrasi Tataguna Lahan 2009

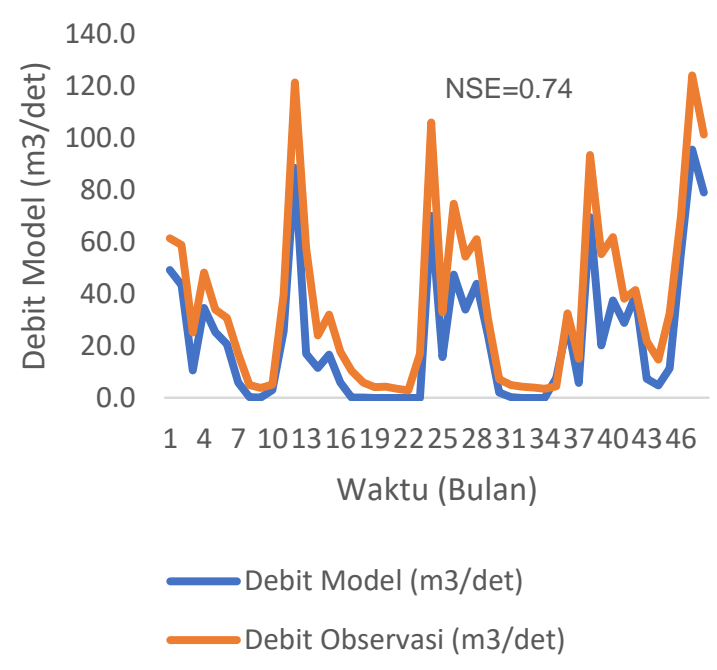

Gambar 10. Grafik Kalibrasi Tataguna Lahan 2017

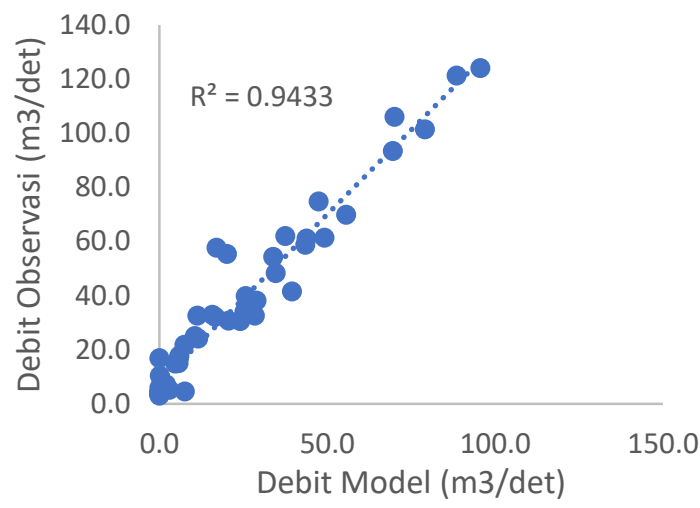

Gambar 11. Scatter Plot Kalibrasi Tataguna Lahan 2017 
Gambar 8 sampai dengan Gambar 11 menunjukkan nilai debit model lebih rendah daripada debit observasi. Hasil grafik-grafik tersebut merupakan hasil optimalisasi dari perubahan parameter. Hasil perhitungan NSE dan $\mathrm{R}^{2}$ meningkatkan daripada hasil simulasi awal yang menyerupai hasil penelitian pada DAS Godavari [6].

\subsubsection{Validasi Model}

Validasi model dilakukan terhadap kedua model tataguna lahan 2009 dan 2017 dengan menggunakan hasil kalibrasi parameter. Validasi pada tataguna lahan 2009 dilakukan terhadap debit tahun 2011-2012 menghasilkan $\mathrm{NSE}=0.87$ dan $\mathrm{R}^{2}=0.91$ (Gambar 12 dan 13) kategori sangat baik. Validasi pada model tataguna lahan 2017 dilakukan terhadap debit tahun 2017-2018 menghasilkan NSE $=0.85$ dan $\mathrm{R}^{2}=0.96$ (Gambar 14 dan 15) kategori sangat baik.

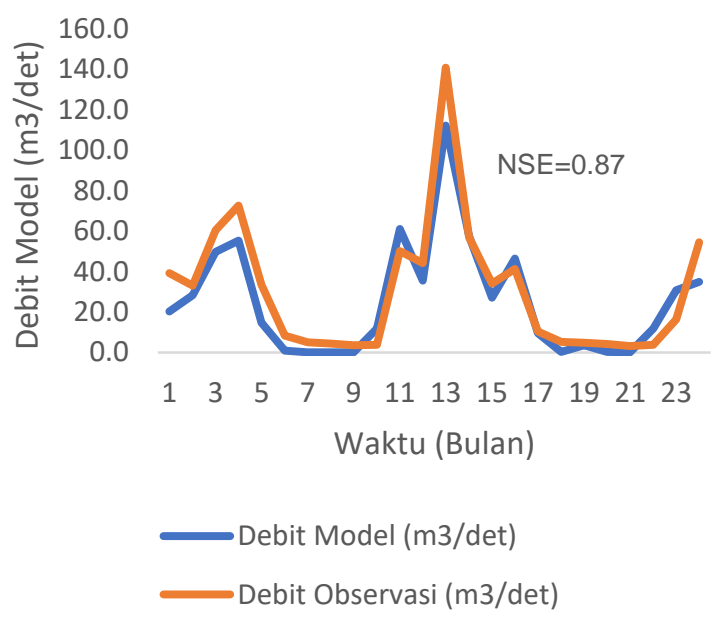

Gambar 12. Grafik Validasi Tataguna Lahan 2009

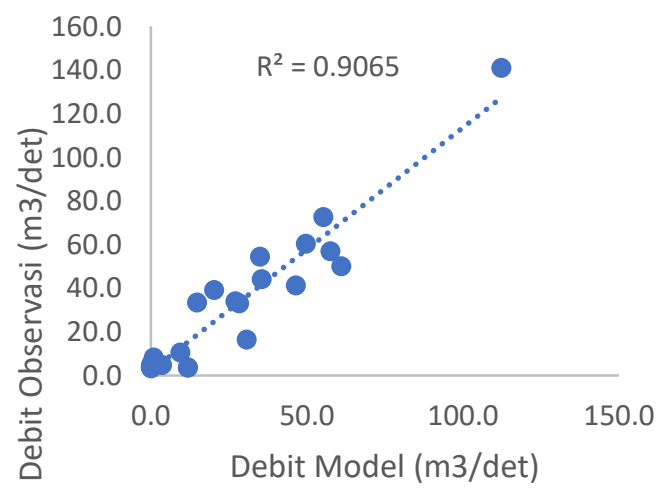

Gambar 13. Scatter Plot Validasi Tataguna Lahan 2009

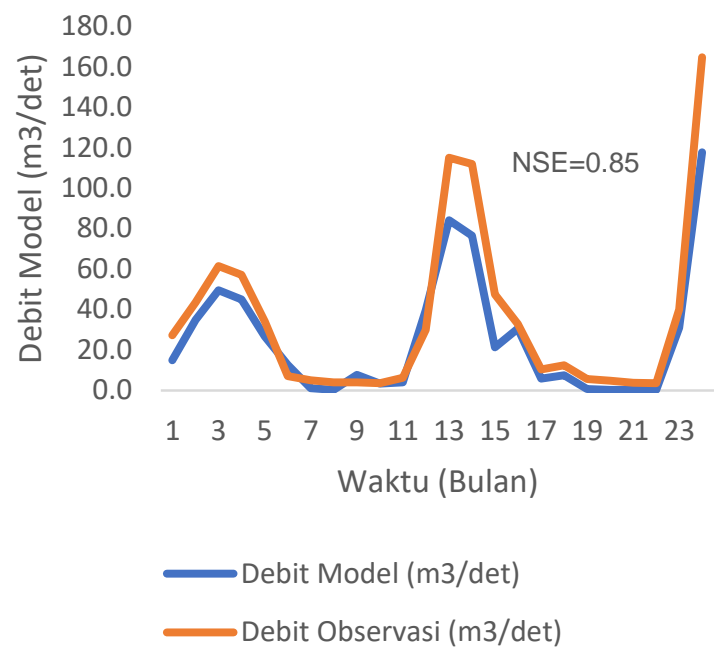

Gambar 14. Grafik Validasi Tataguna Lahan 2017

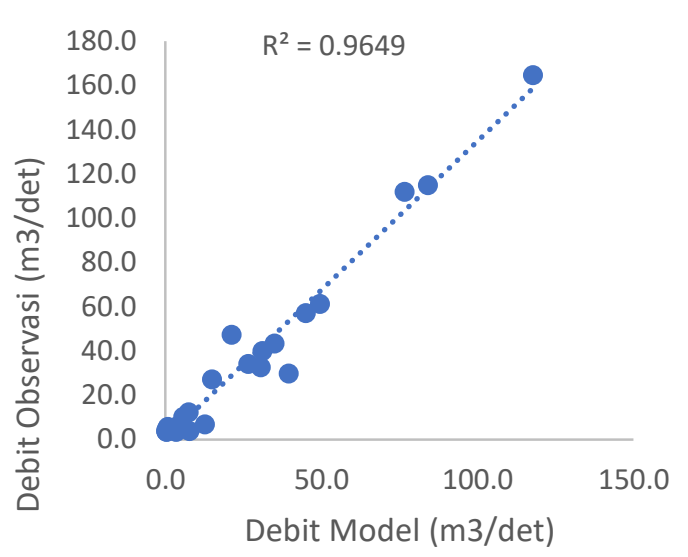

Gambar 15. Scatter Plot Validasi Tataguna Lahan 2017

Hasil validasi pada Gambar 12 sampai dengan Gambar 15 menunjukkan penilaian yang lebih baik dari pada kalibrasi. Pada grafik diatas masih menunjukkan nilai debit model yang berada dibawah debit observasi. Hasil perhitungan NSE dan $\mathrm{R}^{2}$ pada validasi yang meningkat dibandingkan kalibrasi ini menyerupai penelitian pada DAS Mucuri [10]. 4.4.3. Analisis Debit Banjir Terhadap Perubahan Tataguna lahan

Analisis debit banjir pada penelitian ini dilakukan terhadap hasil debit pemodelan perubahan tataguna lahan hutan (hutan lahan kering dan hutan tanaman) tahun 2004, 2009, 2014 dan 2017. Pemodelan ini dilakukan menggunakan data curah hujan 2007-2018 pada semua model tataguna lahan.

Hasil analisis perubahan tataguna lahan 
menggunakan SWAT menghasilkan persentase hutan tataguna lahan 2004 sebesar 32.94\%, 2009 sebesar 32.5\%, 2014 sebesar 31.66\% dan 2017 sebesar 29.36\%. Berdasarkan pemodelan ArcSWAT terhadap model tataguna lahan 2004, 2009, 2014 dan 2017 menghasilkan debit puncak secara berurutan $68.63 \mathrm{~m}^{3} /$ det, 68.76 $\mathrm{m}^{3} / \mathrm{det}, 68.87 \mathrm{~m}^{3} / \mathrm{det}$ and $69.78 \mathrm{~m}^{3} /$ det. Adapun hasil perbandingan antara perubahan tataguna lahan dengan hasil debit pemodelan dapat dilihat pada Gambar 16.

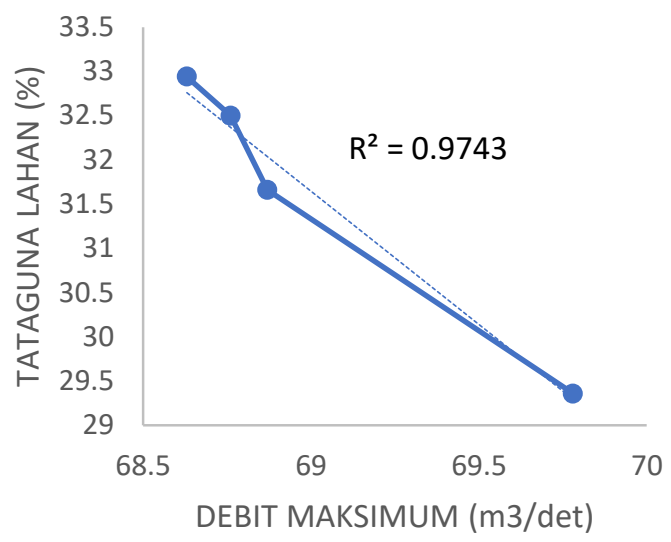

Gambar 16. Perbandingan Perubahan Tataguna Lahan terhadap Debit Model

Berdasarkan Gambar 16 dapat dinyatakan bahwa perubahan tataguna lahan hutan dapat meningkatkan debit banjirPerubahan tataguna lahan hutan sebesar 3.58\% akan menyebabkan kenaikan debit sebesar $2 \%$.

\section{KESIMPULAN DAN SARAN}

\subsection{Kesimpulan}

1. Persentase perubahan tataguna lahan hutan dari tahun 2007 sampai dengan 2017 sebesar $3.58 \%$ atau sama dengan $9.47 \mathrm{~km}^{2}$.

2. Tataguna lahan 2009 pada proses kalibrasi menghasilkan nilai $\mathrm{NSE}=0.78$ dan $\mathrm{R}^{2}$ $=0.84$, pada tahap validasi NSE $=0.87$ dan $\mathrm{R}^{2}=0.91$. Sedangkan tataguna lahan 2017 pada proses kalibrasi menghasilkan nilai $\mathrm{NSE}=0.74$ dan $\mathrm{R}^{2}=0.94$, pada tahap validasi NSE $=0.85$ dan $R^{2}=0.96$.

3. Pemodelan perubahan tataguna lahan hutan DAS Tanggul menggunakan model SWAT dapat meningkatkan debit banjir. Hal ini ditunjukkan dengan penurunan luas hutan sebesar $3.58 \%$ dapat menaikkan $2 \%$ dari debit awal model.

\section{2 .Saran}

Penggunaan peta DEM (Digital Elevation Models) dengan resolusi tinggi agar dapat memodelkan DAS yang menyerupai keadaan sebenarnya.

\section{DAFTAR PUSTAKA}

[1] F. Modeling, F. Financial, L. Analysis, C. Watershed, and I. P. B. Darmaga, "JTI Vol 39 No 2-02-Sisi F.pdf," pp. 75-84, 2015.

[2] A. Tasdighi, M. Arabi, and D. Harmel, "A probabilistic appraisal of rainfall-runoff modeling approaches within SWAT in mixed land use watersheds," J. Hydrol., vol. 564, no. February, pp. 476-489, 2018.

[3] G. Ghaffari, S. Keesstra, J. Ghodousi, and H. Ahmadi, "SWAT-simulated hydrological impact of land-use change in the Zanjanrood Basin, Northwest Iran," Hydrol. Process., vol. 24, no. 7, pp. 892-903, 2010.

[4] F. Githui, F. Mutua, and W. Bauwens, "Estimating the impacts of land-cover change on runoff using the soil and water assessment tool (SWAT): Case study of Nzoia catchment, Kenya," Hydrol. Sci. J., vol. 54, no. 5, pp. 899908, 2009.

[5] T. J. Baker and S. N. Miller, "Using the Soil and Water Assessment Tool (SWAT) to assess land use impact on water resources in an East African watershed," J. Hydrol., vol. 486, pp. 100-111, 2013.

[6] A. Anshuman, T. I. Eldho, and A. KunnathPoovakka, "Performance Evaluation of SWAT with a Conceptual Rainfall-Runoff Model GR4J for a Catchment in Upper Godavari River Basin," Int. Soil Water Assess. Tool Conf. 2018, p. 101, 2018.

[7] E. Junaidi and S. D. Tarigan, "Application SWAT Hydrology Model in Cisadane Watershed Management," J. Penelit. Hutan dan Konserv. Alam, vol. 9, no. 3, pp. 221-237, 2012.

[8] A. C. Cindy Harifa, M. Sholichin, and T. B. Prayogo, "Analisa Pengaruh Perubahan Penutupan Lahan Terhadap Debit Sungai Sub Das Metro Dengan Menggunakan Program Arcswat," J. Teknik Pengair., vol. 008, no. 01, pp. 1-14, 2017.

[9] Naharuddin, Buku Ajar Pengelolaan DAS dan Aplikasinya dalam Proses Belajar Mengajar, 1st ed., no. April. Palu, Sulawesi Tengah: UNTAD Press, 2018.

[10] R. A. Almeida, S. B. Pereira, and D. B. F. Pinto, "Calibration and validation of the SWAT hydrological model for the Mucuri river basin," Eng. Agric., vol. 38, no. 1, pp. 55-63, 2018. 